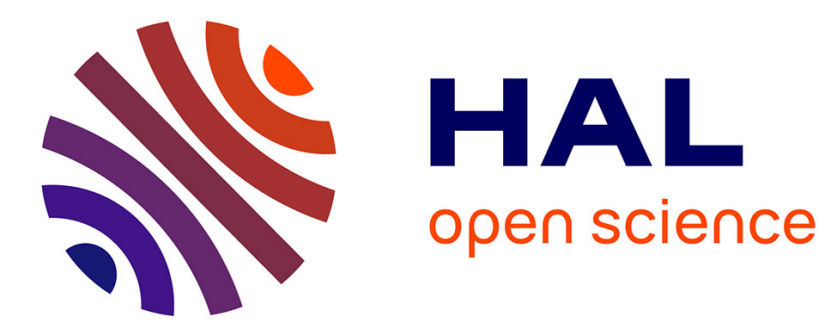

\title{
Study of the early stages of tryptic hydrolysis of $\beta$-casein
} Joëlle Leonil, D. Molle, J.L. Maubois

\section{To cite this version:}

Joëlle Leonil, D. Molle, J.L. Maubois. Study of the early stages of tryptic hydrolysis of $\beta$-casein. Le Lait, 1988, 68 (3), pp.281-294. hal-00929132

\section{HAL Id: hal-00929132 https://hal.science/hal-00929132}

Submitted on 1 Jan 1988

HAL is a multi-disciplinary open access archive for the deposit and dissemination of scientific research documents, whether they are published or not. The documents may come from teaching and research institutions in France or abroad, or from public or private research centers.
L'archive ouverte pluridisciplinaire HAL, est destinée au dépôt et à la diffusion de documents scientifiques de niveau recherche, publiés ou non, émanant des établissements d'enseignement et de recherche français ou étrangers, des laboratoires publics ou privés. 


\title{
Study of the early stages of tryptic hydrolysis of $\beta$-casein
}

\author{
Joëlle LEONIL, D. MOLLE, J.L. MAUBOIS \\ INRA, Laboratoire de Recherches de Technologie Laitière, \\ 65, rue de Saint-Brieuc, 35042 Rennes Cedex, France
}

\section{Summary}

The early stages of tryptic digestion of $\mathrm{BA}_{2}$-casein were investigated using reverse phase high performance liquid chromatography (RP-HPLC) and SDS polyacrylamide gel electrophoresis (SDS-PAGE). The results obtained show that $\beta$-casein degradation included the following events : the fast appearance of two $\mathrm{N}$-terminal peptides (1-25) and (1-28) fragments, the latter being an intermediate product, along with the gradual disappearance of the whole molecule. Splitting of these N-terminal peptides induces the formation of hydrophobic intermediates which may precipitate, depending on the initial $\beta$-casein concentration. Electrophoretic comparison of tryptic and plasmin digests of $\beta$ casein suggests that the precipitate contained mainly, large $\mathrm{C}$-terminal fragments. Further hydrolysis led to the formation of the other stable end-products. Among these, the first three to appear were (100-105), (170-176) and (177-183). The results of this study show that the regions $(\ldots 25-29 \ldots)$ and $(\ldots 105-108 \ldots)$ of the $\beta$-casein are particularly susceptible to the attack by the trypsin.

Key-words: $\beta$-casein - Tryptic hydrolysis - Plasmin - FPLC - Phosphopeptides $\beta$-casein breakdown - Peptides (100-105), (170-176), (177-183).

\section{Résumé}

\section{Etude des premières étapes de l'hydrolyse trypsique de la caséine $\beta$}

L'évolution de l'hydrolyse trypsique de la caséine $\beta \mathrm{A}_{2}$ a été étudiée par chromatographie liquide haute performance (RP-HPLC colonne PEP-RPC). Dès le début de l'hydrolyse, nous avons mis en évidence l'apparition de 2 phosphopeptides : les fragments (1-25) et (1-28), ce dernier étant un peptide intermédiaire. La libération de ces fragments N-terminaux est associée à la formation de fragments très hydrophobes qui précipitent selon la concentration initiale en caséine $\beta$ (supérieure à $1 \mathrm{~g} / \mathrm{l}$ ). La comparaison électrophorétique du précipité avec les produits connus d'hydrolyse de la caséine $\beta$ par la plasmine montre qu'il s'agirait principalement de gros fragments renfermant la séquence $C$-terminale de la caséine $\beta$. Ces fragments peuvent être facilement séparés par chromatographie sur un échangeur d'anions (Mono Q).

L'étude de la cinétique d'apparition des peptides finaux montre que les peptides (100-105), (170-176) et (177-183) sont produits postérieurement aux phosphopeptides (1-25) et (1-28) mais bien avant les autres peptides finaux. 
Il ressort des résultats présentés que les régions $(\ldots 25-29 \ldots)$ et $(\ldots 105-108 \ldots)$ de la caséine $\beta$ sont particulièrement sensibles à l'attaque par la trypsine.

Mots-clés: Caséine $\beta$ - Hydrolyse trypsique - Plasmine - FPLC - Phosphopeptides Fragmentation de la caséine $\beta$ - Peptides (100-105), (170-176), (177-183).

\section{Introduction}

$\beta$-casein represents about $36 \%$ of whole casein of cow's milk (SWAISGOoD, 1982). The complete primary structure of this protein is known (RIBADEAU Dumas et al., 1972). It is a single polypeptide chain which contains 209 amino acid residues including 5 phosphoseryl residues. $\beta$-casein is also characterized by a high proportion of prolyl residues $(16,7 \%)$ which is partly responsible for an open structure (Noelken and Rebstein, 1968 ; Leslie et al., 1969). Recent studies have shown that several peptides arising from the degradation of milk proteins have biological activities. In particular for the $\beta$-casein, opioid activity has been proved by BrANTL et al. (1979) in the sequence 60-66, called $\beta$ casomorphin. The first twenty residues of the same protein contain a phosphopeptide which could be active in the transport of calcium (MIKKANEN and WASSERMAn, 1980). Anti-hypertensive activity was also reported for a peptide representing residues 177-183 (MARUYAma et al., 1985).

Such potential physiological effects require to be studied and confirmed in animal and human therapy by the preparation of significant amounts of purified peptides.

$\beta$-casein can be obtained in large quantities by using tangential membrane microfiltration technology (MauBoIs et al., 1986). Its hydrolysis can be achieved either in batch process or according to the enzymatic membrane reactor procedure previously proposed by MaUBoIs et al. (1979) for the whey proteins and by BRULÉ et al. (1980) for the whole casein. However both techniques lead to a complex mixture of peptides from which it is difficult to extract and to purify individual peptides.

On the other hand, it is well known that the cleavage of peptide bonds does not occur at the same rate and/or at the same time according to both the specificity and the ease of access to the enzyme molecule. Such differences in rate and time of peptide splitting could be advantageously exploited in the membrane reactor technique. However, the execution of this process evidently requires an extensive investigation of the kinetics of the enzymatic reaction in order to determine optimal conditions leading to a differential release of peculiar fragments.

The present investigation was undertaken to get some insight on the kinetic of the tryptic digestion of $\beta$-casein. Reverse phase high-performance liquid chromatography (RP-HPLC) was used to follow the appearance of hydrolyzed fragments over time at different concentrations of $\beta$-casein and $\mathrm{E} / \mathrm{S}$ ratios. The nature of the precipitate associated with the early tryptic degradation of $\beta$-casein was investigated. The feasibility of applying the hydrolysis in enzymatic membrane reactor is discussed. 


\section{Materials and methods}

Uvasol acetonitrile was obtained from Merck (Darmstadt, RFA), N-tosylL-phenylalanine chloromethyl ketone (TPCK)-treated trypsin EC 3.4.21.4 (bovine pancreas, $31 \mathrm{U} / \mathrm{mg}$ ) from Serva (Heidelberg, RFA), soybean trypsin inhibitor and plasmin EC 3.4.4.14 (porcine blood, $4.2 \mathrm{U} / \mathrm{mg}$ ) from Sigma and trifluoroacetic acid (TFA) from Prolabo. All other products were of analytical grade. Buffers and mobile phases were prepared from HPLC grade water (Millipore) and degassed under vacuum. Organic buffers were degassed by ultrasonication (Metason 600, Struers Scientific Instruments, Copenhagen).

\section{A. $\beta$-casein}

$\beta$-casein was purified as described by Mercier et al. (1968) from whole acid casein obtained from milk of cows homozygote for the variant $\beta \mathrm{A}_{2}$. After purification, the $\beta$-casein fraction was dialyzed against water and brought to $\mathrm{pH} 7$ before freeze drying. The concentration of $\beta$-casein in solution was determined spectrophotometrically using the extinction coefficient $\epsilon \underset{278 \mathrm{~nm}}{1 \mathrm{mg} / \mathrm{ml}}=0.46$ (SwaIsGood, 1982).

\section{B. Hydrolysis of $\beta$-casein by the TPCK-treated trypsin and plasmin}

Tryptic digestion was performed at $40{ }^{\circ} \mathrm{C}$ on solutions of $\beta$-casein in $0.1 \mathrm{M}$

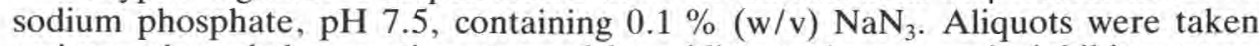
at intervals and the reaction stopped by adding soybean trypsin inhibitor to an $\mathrm{I} / \mathrm{E}=3(\mathrm{w} / \mathrm{w})$. Preliminary experiments showed that the inhibition was immediate and total under these conditions. Plasmin digestion was performed at $40{ }^{\circ} \mathrm{C}$ on $9.10^{-3} \mathrm{mM} \beta$-casein in $0.1 \mathrm{M}$ sodium phosphate, $\mathrm{pH} 7.5$, at an E/S ratio $=7.7 \times 10^{-4}(\mathrm{w} / \mathrm{w})$. The reaction was stopped as described for trypsin.

\section{Chromatography}

The apparatus used was the Pharmacia Fast Protein Liquid Chromatography (FPLC) system fitted with either a $\mathrm{C}_{18}$ PEP-RPC or an anionic exchanger Mono Q column $(0.5 \times 5 \mathrm{~cm})$. The equipment consisted of a LCC-500 system controller, two P500 pumps, an UV detector $(214$ or $280 \mathrm{~nm}$ ) and a FRAC 100 collector. Elution was carried out as described in "Results ». Two elution systems were used to verify the purity of eluted peptides. The first was $20 \mathrm{mM}$ Na-phosphate buffer, pH 6.7 (buffer A) containing acetonitrile $(60 \%$; v/v ; $\mathrm{pH}=8.25$ ), the second was $0.1 \%$ TFA (solvent A) containing acetonitrile $(60 \%, v / v)$.

\section{Electrophoresis}

Sodium dodecyl sulfate polyacrylamide gel electrophoresis (SDS-PAGE) was performed in a vertical slab gel apparatus according to LAEMmLI (1970); a 
gel at $\mathrm{pH} 8.6$ containing $4.5 \mathrm{M}$ urea with an acrylamide gradient from 10 to $20 \%$ was used. Electrophoresis was performed at 60 volts with variable current until the Bromophenol Blue entered the separation gel. Then a voltage of 100 volts was applied. The tracking dye took twelve hours to reach the bottom of the gel. Pharmacia molecular weight markers were used to calibrate the gels (Polypeptide Kit: Myoglobin 17200, Myoglobin I + II 14600, Myoglobin I 8240, Myoglobin II 6380, Myoglobin III 2560).

PAGE was performed on a polyacrylamide gel with a gradient from 7 to $14 \%$ acrylamide, according to LAEMmLI (1970). The voltage applied to the stacking gel was 60 volts for two hours and 120 volts for seven hours for separation. Dimensions of the plates were $140 \times 160 \times 1.2 \mathrm{~mm}$.

Proteins and peptides were fixed by soaking the gels immediately after the run in $12 \% \mathrm{TCA}$ for 4 hours ; subsequently, the gels were stained according to BlaKesley and Boezi (1977).

\section{E. Amino acid analysis}

Amino acid analysis of samples hydrolyzed for 24 hours in $6 \mathrm{~N} \mathrm{HCl}$ at $110{ }^{\circ} \mathrm{C}$ under vacuum were performed with a BECKMAN Automatic Amino Acid Analyzer.

\section{Results}

\section{A. Time course of tryptic hydrolysis of $\beta$-casein by HPLC}

The action of trypsin was studied in batch at a $\beta$-casein concentration of $2.08 \times 10^{-2} \mathrm{mM}$ and a molar ratio, E/S, $1 / 10000$. After the reaction had been stopped, samples were applied directly to the PEP-RPC column. A blank sample containing buffer, trypsin and soybean inhibitor gave a flat baseline with only one peak corresponding to $\mathrm{NaN}_{3}$. The progress of tryptic digestion of $\beta$-casein was followed as shown in fig. 1. All peptides were eluted in less than $30 \mathrm{~min}$ with a linear gradient from $20 \mathrm{mM}$ sodium phosphate, $\mathrm{pH} 6.7$ (buffer A) to acetonitrile in buffer $\mathrm{A}(60 / 40 ; \mathrm{v} / \mathrm{v} ; \mathrm{pH}=8.25)$. During the early stages of hydrolysis, peptides appeared in the hydrophobic part of gradient and some of these were more hydrophobic than intact $\beta$-casein. The presence of two well-resoluted peaks (fig. 1c, I and II) was also noted in the first third of the elution gradient. The first one corresponded to a stable end-product, the concentration of which increased with the time of hydrolysis, whereas the second was produced only during the initial stages of digestion and disappeared thereafter. Except peak I, during the first $20 \mathrm{~min}$, all other peaks were intermediate products as indicated by comparison of the chromatograms of the $20 \mathrm{~min}$ and 27 hours samples (fig. 1). The disappearance of whole $\beta$-casein occurred after about $60 \mathrm{~min}$ (fig. 1d). Concomitantly, other stable endproducts appeared which increased with time and gave the peptidic profile shown in fig. If.

In other experiments, fragments resulting from tryptic digestion at the same $\mathrm{E} / \mathrm{S}$ molar ratio (i.e. $\mathrm{E} / \mathrm{S}=1 / 10000$ ) as in the first experiment but at a 


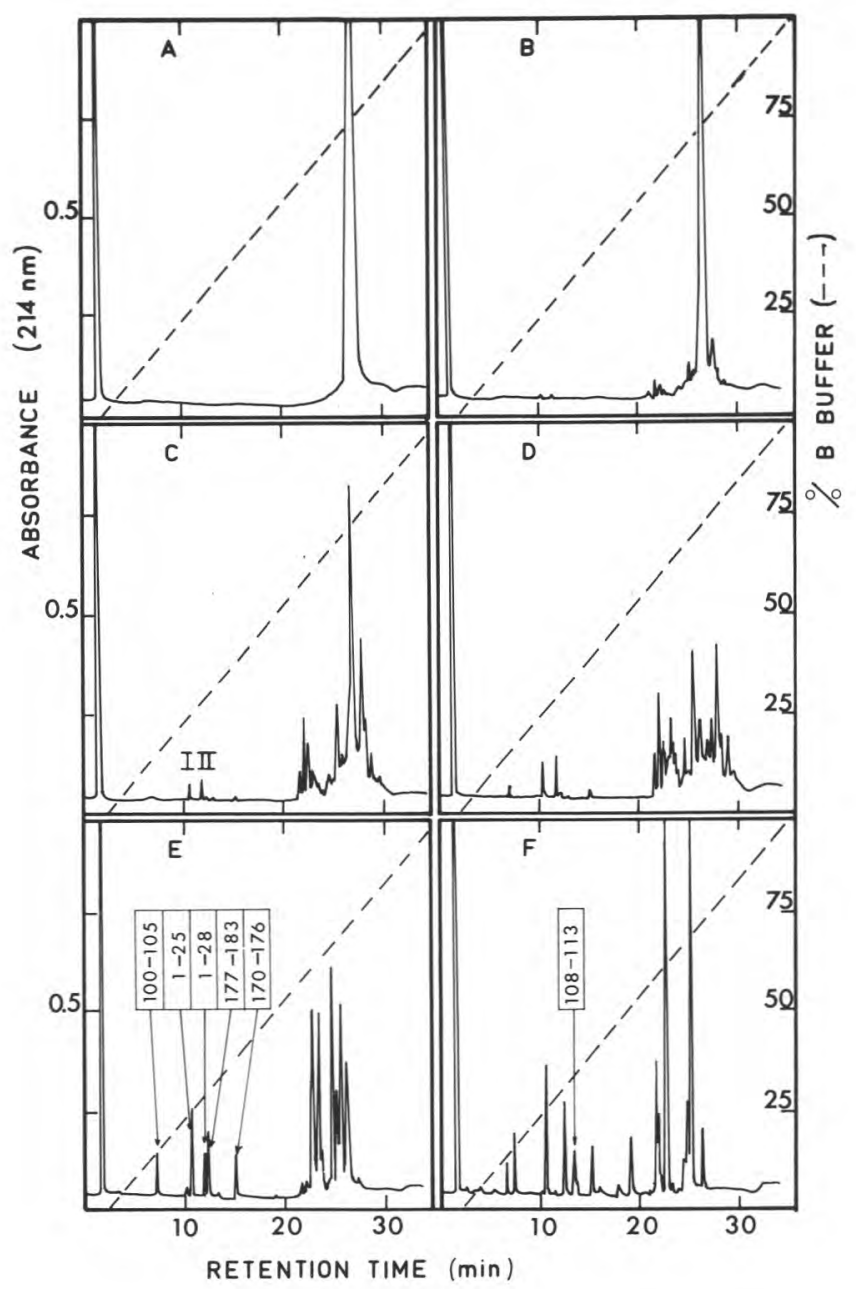

Fig. 1

Time course of tryptic digestion of $\beta$-casein. $\beta$-casein concentration $2.08 \times 10^{-2} \mathrm{mM}$. $E / S=1 / 10000$. Elution by linear gradient from $20 \mathrm{mM} \mathrm{Na}$ phosphate buffer $\mathrm{pH} 6.7$ (buffer $A)$ to acetonitrile/buffer $A(60 \% ; v / v), p H 8.2$ (buffer B). Flow rate: $1 \mathrm{ml} / \mathrm{min}$; and $40^{\circ} \mathrm{C}$; column : PEP-RPC (Pharmacia).

Hydrolysis times: $A, 0 \mathrm{~min}$; $B, 2 \mathrm{~min} ; C, 20 \mathrm{~min} ; D, 60 \mathrm{~min} ; E, 4 \mathrm{~h} ; \mathrm{F}, 27 \mathrm{~h}$. Evolution en fonction du temps de l'hydrolyse trypsique de la caséine $\beta$. Concentration en caséine $\beta: 2,08 \times 10^{-2} \mathrm{mM}$. E/S=1/10000. Elution par un gradient linéaire du tampon $A$ (phosphate de sodium $20 \mathrm{mM}, \mathrm{pH} \mathrm{6,7)} \mathrm{au} \mathrm{tampon} B$ (acétonitrile/tampon $A$, $60 \% \mathrm{v} / \mathrm{v}, \mathrm{pH} 8,2)$. Débit $1 \mathrm{ml} / \mathrm{mn}, 40^{\circ} \mathrm{C}$. Colonne PEP-RPC (Pharmacia).

Temps d'hydrolyse A, $0 \mathrm{mn} ; B, 2 \mathrm{mn} ; C, 20 \mathrm{mn} ; \mathrm{D}, 60 \mathrm{mn} ; \mathrm{E}, 4 \mathrm{~h}$ et $\mathrm{F}, 27 \mathrm{~h}$. 
casein concentration of $4.1 \times 10^{-1} \mathrm{mM}$, were studied. At this concentration, ANDREws et al. (1979) have shown that $\beta$-casein exists in an aggregated state. It is well known that at room temperature and above a critical concentration (CMC), $\beta$-casein forms micelles while it occurs as monomers at low temperature or below to the CMC (ScHMIDT, 1982). Although the concentration was twenty times higher, the overall pattern of proteolysis during the early stages was similar to that obtained in the former experiment. At $45 \mathrm{~min}$, a marked opalescence appeared in the reaction mixture which finally led to a precipitate. Precipitation was immediate at $\mathrm{E} / \mathrm{S}=1 / 100$. In both cases, the insolubilization was temporary and decreased as the reaction proceeded. Analysis of the precipitate by RP-HPLC after centrifugation and solubilization in $10 \%$ acetic acid showed that this fraction was very hydrophobic (fig. 2b). The two peaks I, II, previously described as well as a group of poorly resoluted peaks were recovered in the supernatant (fig. 2a).

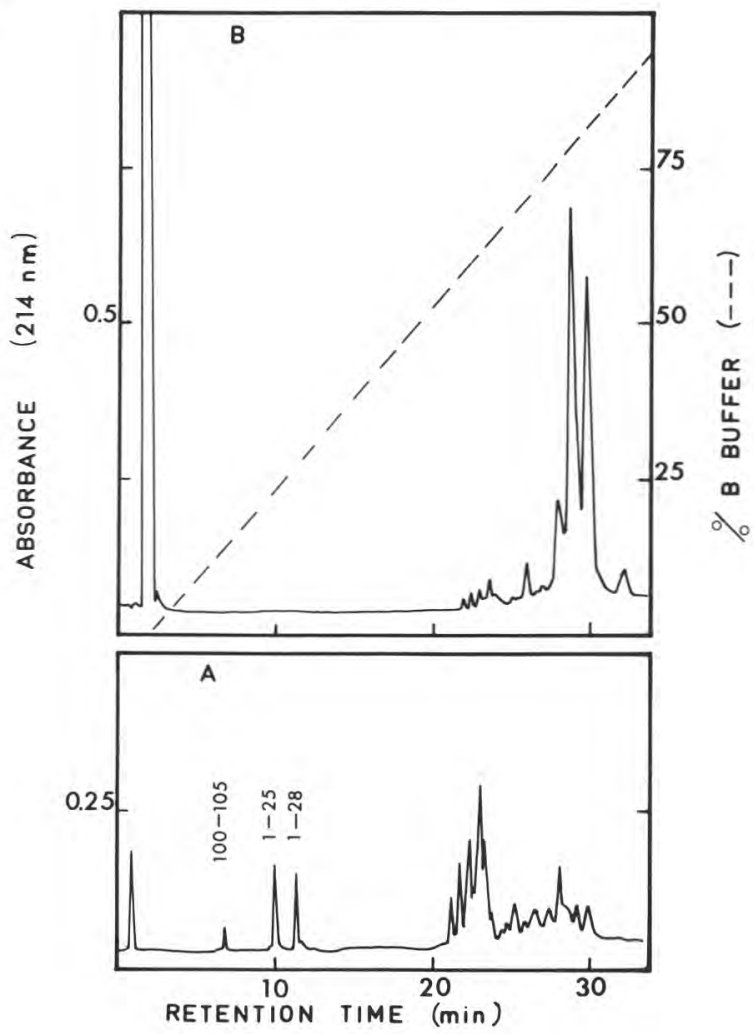

Fig. 2

$C_{18}$ PEP-RPC analysis of supernatant $(A)$ and pellet $(B)$ obtained after centrifugation of the reaction mixture $\left(E / S=1 / 10000, \beta\right.$-casein concentration : $4.1 \times 10^{-1} \mathrm{mM}$, hydrolysis time: $45 \mathrm{~min})$. Elution conditions as in figure 1.

Profil chromatographique sur PEP-RPC du surnageant $(A)$ et du culot $(B)$ obtenus après centrifugation de l'hydrolysat trypsique de la caséine $\beta(E / S=1 / 10000$, concentration en caséine $\beta 4,1 \times 10^{-1} \mathrm{mM}$, temps d'hydrolyse $45 \mathrm{mn}$ ). Conditions d'élution identiques à celles de la figure 1. 
TABle 1

Amino acid composition of peptides (1-25), (1-28), (100-105), (170-176), (177-183), (108-113)

Composition en acides aminés des peptides (1-25), (1-28), (100-105), (170-176), (177-183), (108-113)

\begin{tabular}{|c|c|c|c|c|c|c|c|c|c|c|c|c|}
\hline \multirow{2}{*}{$\begin{array}{c}\text { Peptides } \\
\text { Amino } \\
\text { acid }\end{array}$} & \multicolumn{2}{|c|}{ Peak I (1-25) } & \multicolumn{2}{|c|}{ Peak II (1-28) } & \multicolumn{2}{|c|}{ Peak (100-105) } & \multicolumn{2}{|c|}{ Peak (108-113) } & \multicolumn{2}{|c|}{ Peak (170-176) } & \multicolumn{2}{|c|}{ Peak (177-183) } \\
\hline & $\begin{array}{l}\text { Molar } \\
\text { ratio }\end{array}$ & $\begin{array}{l}\text { Nearest } \\
\text { integer }\end{array}$ & $\begin{array}{l}\text { Molar } \\
\text { ratio }\end{array}$ & $\begin{array}{l}\text { Nearest } \\
\text { integer }\end{array}$ & $\begin{array}{l}\text { Molar } \\
\text { ratio }\end{array}$ & $\begin{array}{l}\text { Nearest } \\
\text { integer }\end{array}$ & $\begin{array}{l}\text { Molar } \\
\text { ratio }\end{array}$ & $\begin{array}{l}\text { Nearest } \\
\text { integer }\end{array}$ & $\begin{array}{l}\text { Molar } \\
\text { ratio }\end{array}$ & $\begin{array}{l}\text { Nearest } \\
\text { integer }\end{array}$ & $\begin{array}{l}\text { Molar } \\
\text { ratio }\end{array}$ & $\begin{array}{l}\text { Nearest } \\
\text { integer }\end{array}$ \\
\hline Asx & 1.25 & $1(1)$ & 1.98 & $2(2)$ & - & - & - & - & - & - & - & - \\
\hline Thr & 1.10 & $1(1)$ & 0.97 & $1(1)$ & - & - & - & - & - & - & - & - \\
\hline Ser & 4.32 & $4(5)$ & 4.08 & $4(5)$ & - & - & - & - & - & - & - & - \\
\hline Glx & 6.70 & $7(7)$ & 6.90 & $7(7)$ & 1.04 & $1(1)$ & 1.07 & $1(1)$ & 1.00 & $1(1)$ & 1.08 & $1(1)$ \\
\hline Pro & 1.05 & $1(1)$ & 1.10 & $1(1)$ & 1.00 & $1(1)$ & 1.90 & $2(2)$ & 1.90 & $2(2)$ & 2.00 & $2(2)$ \\
\hline Gly & 1.00 & $1(1)$ & 1.19 & $1(1)$ & - & - & - & - & - & - & - & - \\
\hline Ala & - & - & - & - & 1.80 & $2(2)$ & - & - & - & - & 0.90 & $1(1)$ \\
\hline Val & 1.70 & $2(2)$ & 1.70 & $2(2)$ & - & - & - & - & 2.00 & $2(2)$ & 1.02 & $1(1)$ \\
\hline Met & - & - & - & - & 0.90 & $1(1)$ & 0.90 & $1(1)$ & - & - & - & - \\
\hline Ile & 1.85 & $2(2)$ & 3.03 & $3(3)$ & - & - & - & - & - & - & - & - \\
\hline Leu & 2.89 & $3(3)$ & 3.20 & $3(3)$ & - & - & - & - & 0.92 & $1(1)$ & - & - \\
\hline Tyr & - & - & - & - & - & - & - & - & - & - & - & - \\
\hline Phe & - & - & - & - & - & - & 1.00 & $1(1)$ & - & - & 1.00 & $1(1)$ \\
\hline Lys & - & - & 1.02 & $1(1)$ & 1.00 & $1(1)$ & 1.00 & 1 (1) & 1.00 & $1(1)$ & - & - \\
\hline His & - & - & - & - & - & - & - & - & - & - & - & - \\
\hline Arg & 1.90 & $2(2)$ & 2.00 & $2(2)$ & - & - & - & - & - & - & 1.00 & $1(1)$ \\
\hline $\begin{array}{l}\text { Total } \\
\text { residues }\end{array}$ & & $24(25)$ & & $27(28)$ & & $6(6)$ & & $6(6)$ & & $7(7)$ & & $7(7)$ \\
\hline
\end{tabular}

a) Theoretical values are shown in brackets. 
Peaks I and II were identified by amino acid analysis (table 1). They corresponded to peptides (1-25) and (1-28), respectively. The low values in Ser were due to the extensive phosphorylation of this amino acid which is known to lead to low recoveries.

\section{B. Characterization of the precipitate}

The occurrence of a precipitate in the course of tryptic hydrolysis of $\beta$-casein had already been observed by CHRISTENSEN (1954). We have noted that precipitation became perceptible at concentrations of $\beta$-casein about $4.08 \times 10^{-2} \mathrm{mM}(1 \mathrm{~g} / \mathrm{l})$. Of course, its rate of disappearance depended on the $\mathrm{E} / \mathrm{S}$ ratio. The pellet recovered by centrifugation was analysed using an anionic exchanger, Mono Q column, equilibrated and eluted with a Tris- $\mathrm{HCl}$, $\mathrm{pH} 7$, buffer. Urea was used in the buffer to avoid precipitation of this poorlysoluble fraction during the chromatographic procedure. The elution profile is shown in fig. 3. Six fractions were obtained. The last peak was identified as

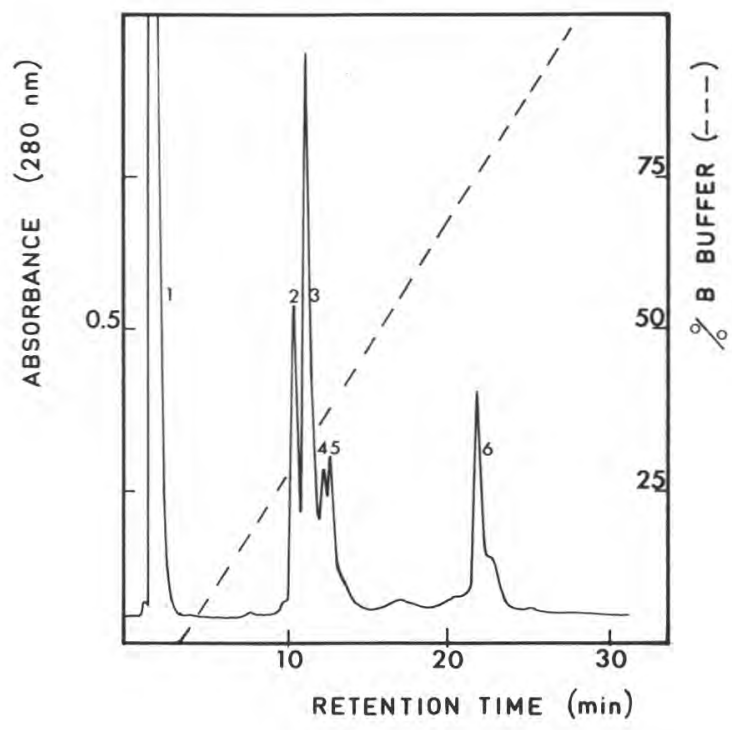

Fig. 3

FPLC analysis of the pellet using a Mono $Q$ column. $\beta$-casein concentration : $4.1 \times 10^{-1}$ $\mathrm{mM} ; E / \mathrm{S}=1 / 10000, t: 1$ hour. Samples dissolved in $20 \mathrm{mM}$ TRIS-HCl buffer $\mathrm{pH} 7.8$ containing $4.5 \mathrm{M}$ urea were applied to the column equilibrated with the same buffer and eluted at a flow rate of $1 \mathrm{ml} / \mathrm{min}$ with a 0-0.35 M NaCl gradient. 6, residual $\beta$-casein. Analyse du culot en FPLC sur colonne Mono $Q$. Concentration en caséine $\beta=4,1 \times 10^{-1} \mathrm{mM} ; E / S=1 / 10000, t: 1$ heure. L'échantillon dissous dans du tampon TRIS-HCl $20 \mathrm{mM}$ pH 7,8 contenant de l'urée 4,5 M était injecté sur la colonne équilibrée avec le même tampon. L'élution était effectuée avec un gradient de $\mathrm{NaCl}$ de $\mathrm{O}$ à $0,35 \mathrm{M}$ dans le même tampon. Débit $1 \mathrm{ml} / \mathrm{mn}$. 6, caséine $\beta$ résiduelle. 
undigested $\beta$-casein. Other fractions, as confirmed by SDS-PAGE (plate 1), were heterogeneous. The first peak 1 (slot $f$ ) was constituted of different bands with apparent molecular weights between 10000 and 17000 daltons. Peaks 2, 3,4 and 5 (slots $\mathrm{g}, \mathrm{h}, \mathrm{i}, \mathrm{j}$ ) eluted with a $\mathrm{NaCl}$ gradient contained a main band with a molecular weight of about 20000-21 000 daltons ( $\mathrm{rf}$ to molecular weight of $\beta$-casein).

Fractions obtained from the Mono Q column were difficult to characterize by their amino acid composition because of their heterogeneity.

In the other hand, plasmin, the main proteinase in milk, possesses trypsinlike specificity with a preference for lysine residues (WEINSTEIN and DooliTTLE, 1972). As the digestion products of $\beta$-casein by plasmin were known (ANDREws and Alichanidis, 1983), we compared by electrophoresis the first stages of the tryptic and plasmin hydrolysis of $\beta$-casein. Plate 2 showed that there was a similarity between the patterns of the two hydrolysates (slots b, c, $\mathrm{d}$ compared to $\mathrm{m}, \mathrm{n}, \mathrm{o}$ ). Some peptides present in fractionated pellet were very similar in mobility to the C-terminal fragments $\gamma_{1}$ (residues 29-209), $\gamma_{2}$ and $\gamma_{3}$ (respectively residues 106-209 and 108-209) caseins. The supernatant

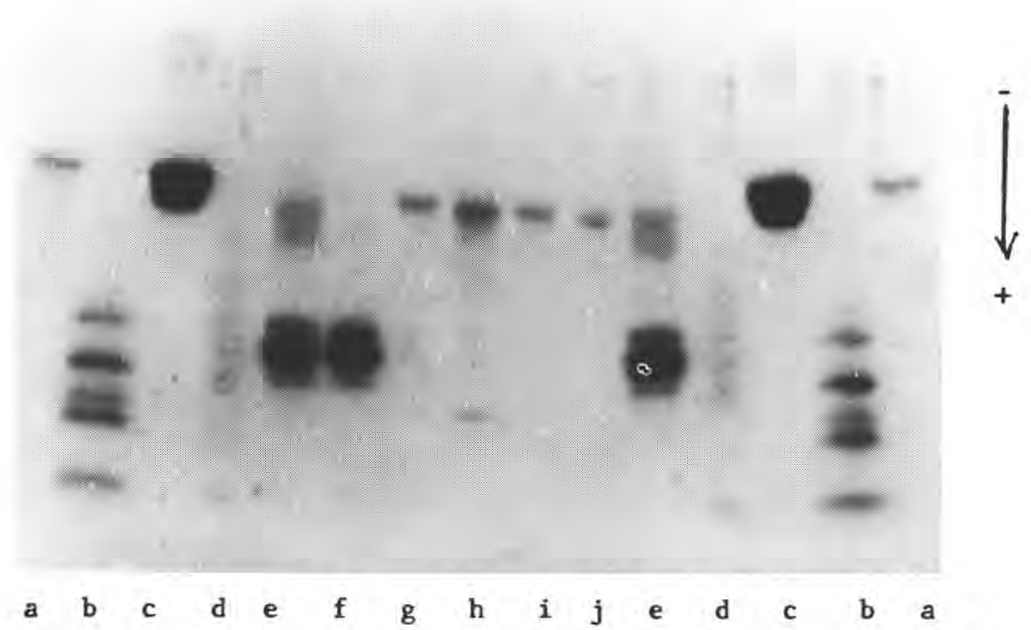

Plate 1

Analysis by SDS-PAGE with a 10-20\% acrylamide gradient of fractions obtained by chromatography of pellet on the Mono $Q$ ion exchanger. Hydrolysis conditions as described in figure 3.

a) fraction 6 ; b) molecular weight markers ; c) control $\beta$-casein with soybean inhibitor ; d) supernatant ; e) pellet; $f$-j) fractions 1 to 5 respectively.

Electrophorèse-SDS (gel à gradient en acrylamide 10-20\%) des fractions récupérées après passage du culot sur échangeur d'anions (Mono Q). Les conditions d'hydrolyse sont celles décrites en figure 3.

a) fraction 6 ; b) marqueurs de poids moléculaire ; c) caséine $\beta+$ inhibiteur de soja ;

d) surnageant; e) culot ; f-j) respectivement fractions 1 à 5. 
(slot e, plate 2) contained fragments which had electrophoretic mobilities close to fragments PP5 (residues 1-105 and 1-107) and PP8F (residues 1-28) (ANDREWS and Alichanidis, 1983). According to results reported previously, it was probable that the last fast-moving component contained not only fragment 1-28 but also peptide 1-25 which were indistinguishable by this method.

\section{Release of first stable end-peptides}

During the breakdown of $\beta$-casein, the sequential release of some stable tryptic peptides was followed by RP-HPLC for peptides and by anion exchange chromatography (Mono Q) for residual $\beta$-casein. Conditions of hydrolysis were such as the precipitation did not occur $(E / S=1 / 10000$, concentration of $\beta$-casein $2.08 \times 10^{-2} \mathrm{mM}$ ). Peptides were identified by their amino acid compositions (table 1). Fig. 4 indicated that the rates of formation of peptides 1-25

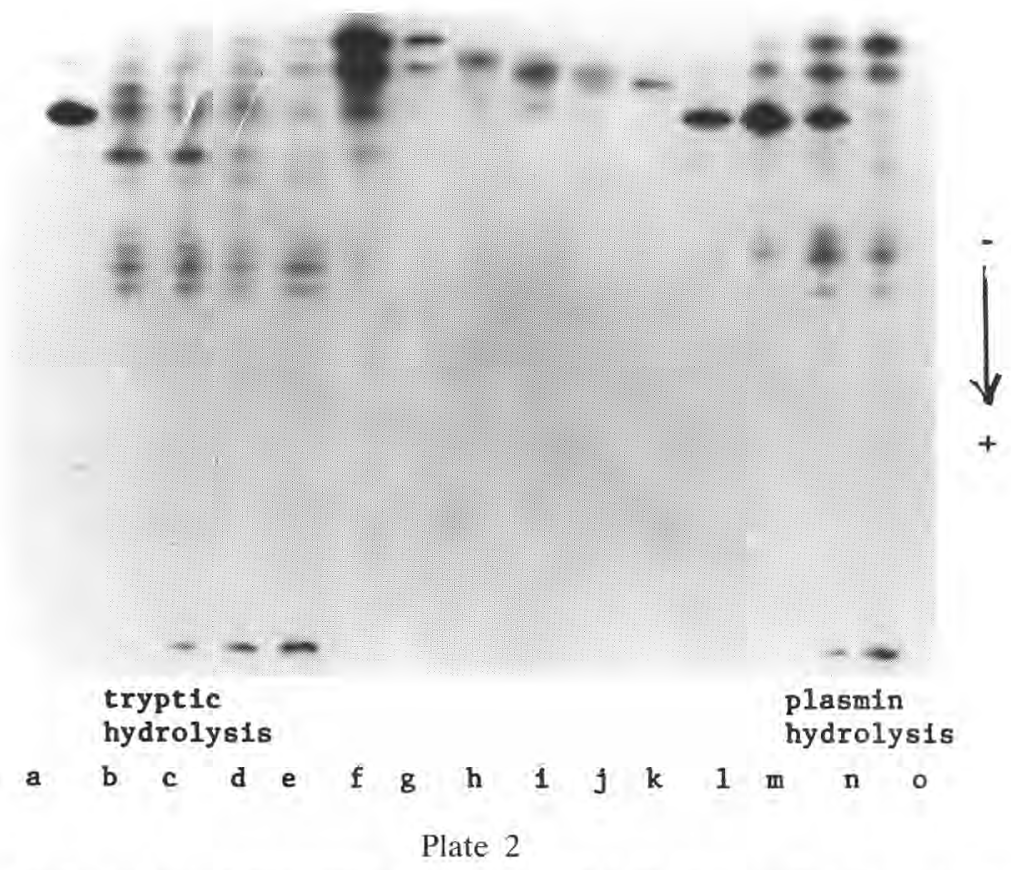

Analysis by polyacrylamide gel electrophoresis with a 7 to $14 \%$ acrylamide gradient and with 4.5 M. urea. Hydrolysis conditions as described in figure 3.

a) B-casein + soybean trypsin inhibitor; b-d) tryptic hydrolysis times 2, 12 and 40 min ; e) supernatant at $60 \mathrm{~min}$; f) pellet at $60 \mathrm{~min}$; $\mathrm{g}$-l) Mono $Q$ fractions $1,2,3,4,5,6$; $\mathrm{m}$-o) plasmin hydrolysis times 15,45 and $150 \mathrm{~min}$.

Electrophorèse (gel à gradient en acrylamide 7-14\% et en présence d'urée $4.5 \mathrm{M}$ ). Les conditions d'hydrolyse sont celles décrites en figure 3.

a) caséine $\beta+$ inhibiteur de soja ; b-d) hydrolysat trypsique de la caséine $\beta$, temps 2,12 et $40 \mathrm{mn}$; e) surnageant ; f) culot; $g$-l) respectivement fractions de 1 à 6 récupérées en sortie de colonne Mono $Q ; m-o)$ hydrolyse par la plasmine de la casétne $\beta$. Temps 15 , 45 et $150 \mathrm{mn}$. 


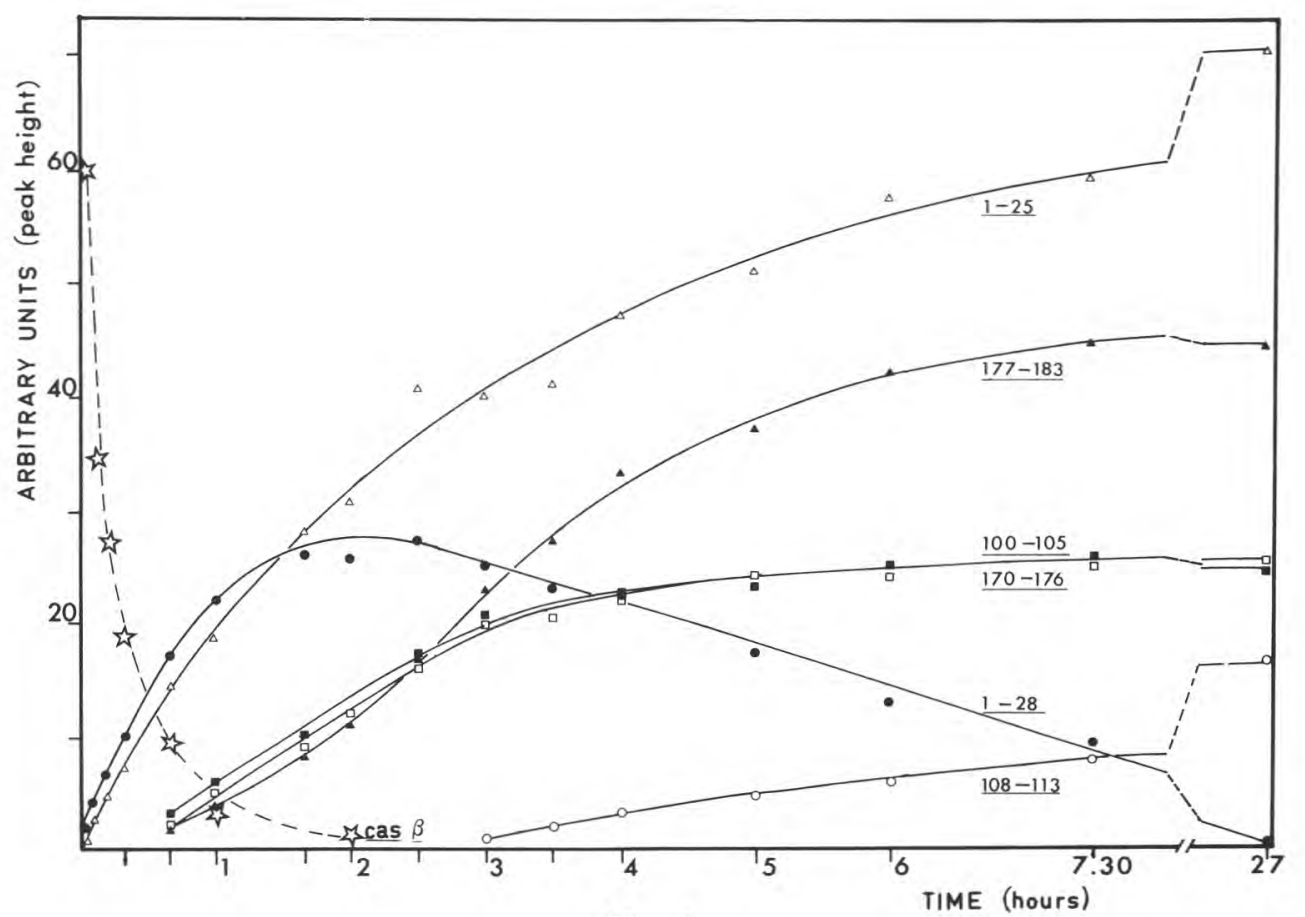

Fig. 4

Kinetics of formation of the first stable end-products, and the intermediate peptide (1-28) studied by RP-HPLC at $214 \mathrm{~nm}$ (-) and the disappearance of $\beta$-casein studied by anion-exchange chromatography (Mono $Q$ column) at $280 \mathrm{~nm}(--$-). $E / S=1 / 10000$ (molar ratio). $\beta$-casein $2.08 \times 10^{-2} \mathrm{mM}$.

Cinétique d'apparition des premiers peptides finaux et $d u$ phosphopeptide intermédiaire (1-28) étudiée sur colonne PEP-RPC à $214 \mathrm{~nm}$ (-) et cinétique de disparition de la caséine $\beta$ étudiée sur colonne Mono $Q$ à $280 \mathrm{~nm}$ (-.-). E/S=1/10000 (rapport molaire). Caséine $\beta: 2,08 \times 10^{-2} \mathrm{mM}$.

and 1-28 were similar. The disappearance of $\beta$-casein was strongly associated with the appearance of fragments $100-105,170-176$ and 177-183. Formation of other stable end-products occurred later, for instance peptide 108-113. The C-terminal tryptic fragment 203-209 ( $\mathrm{Tr} 18.5 \mathrm{~min}$ ) was released after more than 4 hours (data not shown).

\section{Discussion}

Our results show that simultaneously with the gradual disappearance of the whole molecule, tryptic hydrolysis of $\beta$-casein leads to the rapid appearance of two N-terminal phosphopeptides identified as 1-25 and 1-28 fragments, the latter being an intermediate product. Because of this rapid release 
of the polar part of the molecule during the early stages of hydrolysis, very hydrophobic intermediate fragments are also formed, some of these being more hydrophobic than whole $\beta$-casein. According to the E/S ratio and to the initial content in $\beta$-casein (above $1 \mathrm{~g} / 1$ or $4.08 \times 10^{-2} \mathrm{mM}$ ), a progressive and temporary insolubilization of these apolar peptides occurred. Further hydrolysis of theses led to soluble and stable end-peptides, already described by RIBAdeau Dumas et al., 1970 ; Carles and Ribadeau Dumas, 1986.

Indeed, reverse phase HPLC observations combined with SDS-PAGE electrophoregrams and amino acid analysis led to the conclusion that during tryptic hydrolysis, the 25-26 lysyl bond and the 28-29 arginyl bond are among the first cleavage sites. With the progress of enzymatic action, the 1-28 phosphopeptide is slowly converted to the 1-25 phosphopeptide and probably into the 26-28 tripeptide. This last fragment which appears in the start of the elution gradient in RP-HPLC is, indeed, difficult to quantify because of its low absorbance. Our results complement those of REIMERDES (1979) who showed, by electrophoresis, that during the primary stages of $\beta$-casein hydrolysis by immobilized trypsin, cleavages at positions 28-29, 105-106 and 107-108 occurred. Although, in our studies, peptides resulting from cleavage of 105-106 and of 107-108 bonds were not investigated, such cleavages are suggested because of the subsequent formation of $100-105$ and 108-113 peptides (fig. 4) themselves resulting possibly from the breakdown of 1-105 and 108-209 fragments.

On the other hand, as shown by PAGE (plate 2) it appears that the first steps of tryptic $\beta$-casein hydrolysis are very similar to those of $\beta$-casein hydrolysis by plasmin. Bands having electrophoretic mobilities close to those of proteose-peptone components were present in the supernatant fraction of tryptic hydrolysate. It is very likely that hydrolysis of $\beta$-casein by trypsin leads to the temporary formation of PP5 and PP8 F fragments. Consequently, the remaining fragments must be close to the $\gamma$-caseins. The electrophoretic behaviour of the components of the precipitate occurring in tryptic degradation of $\beta$-casein agrees with this hypothesis. These precipitated fragments have similar basicity and high hydrophobicity.

The rapid release of fragment 177-183 and in a lesser extent, of the fragment 170-176 suggests that there are also in the hydrophobic segment of $\beta$ casein three sites easily accessible to trypsin-like proteases.

In the breakdown of $\beta$-casein by trypsin, it appears that a relatively stable intermediate step can be obtained under limited proteolysis conditions. Several fragments differing markedly in their physico-chemical characteristics, such as solubility, electrical charge and size, are released. Advantage could be taken of these differences in continuous hydrolysis technologies realized with a membrane reactor as used by Roger (1979). Fast splitting of 25-26 and of 28-29 bonds could be utilized to obtain an ultrafiltrate enriched in these $\mathrm{N}$-terminal peptides containing phosphoseryl groups. It will be the same for the fragment 177-183 which was shown by MARUYAMA et al. (1985) to have anti-hypertensive properties. However, before such applications of our results can be made, numerous investigations are required in the optimization of hydrolysis parameters: substrate concentration above or below the CMC (the influence of aggregation on hydrolysis kinetics is unknown), E/S ratio, temperature, yields 
of cleavage of the different peptide bonds. It is likely that the hydrophobic precipitate formed in the UF reactor will influence transfer mechanisms such as permeation rate and retention coefficients.

Reçu le 23 septembre 1987.

Accepté pour publication le 11 janvier 1988.

\section{Acknowledgements}

The authors thank Mr. M. PIOT for performing the amino acid analysis.

\section{References}

Andrews A.L., Atkinson D., Evans M.T.A., Finer E.G., Green J.P., Phillips M.C., RobertSON R.N., 1979. The conformation and aggregation of bovine $\beta$-casein A. I. Molecular aspects of thermal aggregation. Biopolymers, 18, 1105-1121.

Andrews A.T., Alichanidis E., 1983. Proteolysis of caseins and the proteose-peptone fraction of bovine milk. J. Dairy Res., 50, 275-290.

BLAKESLEy R.W., Boezı J.A., 1977. A new staining technique for proteins in polyacrylamide gels using Coomassie Brilliant Blue G-250. Anal. Biochem, 82, 580-582.

Brantl V., Teschemacher H., Henschen A., Lottsperch F., 1979. Novel opioid peptides derived from casein ( $\beta$-casomorphins). Hoppe-Seyler's Z. Physiol. Chem., 360, S, 1211-1216.

Brulé G., Roger L., Fauquant J., Piot M., 1980. Procédé de traitement d'une matière première à base de caséine, contenant des phosphocaséinates de cations bivalents. Produits obtenus et applications. Brevet Français, $\mathrm{n}^{\circ} 8002280$.

Brulé G., Roger L., Fauquant J., Piot M., 1980. Procédé de traitement d'une matière première à base de caséine, contenant des phosphocaséinates de cations monovalents ou leurs dérivés. Produits obtenus et applications. Brevet Français, $n^{\circ} 8002281$.

Carles C., Ribadeau Dumas B., 1986. Determination of gradient elution conditions for the separation of peptide mixture by reversed-phase high-performance liquid chromatography: bovine $\beta$-casein tryptic digest. J. Dairy Res., 53, 595-600.

Christensen L.R., 1954. The action of proteolytic enzymes on casein proteins. Arch. Biochem. Biophys., 53 (1), 128-137.

Laemml U.K., 1970. Cleavage of structural proteins during the assembly of the head of bacteriophage T. 4 . Nature, $227,680-685$.

Leslie R.B., Irons L., Chapman D,, 1969. High-resolution nuclear magnetic resonance studies of $\alpha_{s 1}, \beta$ - and $\kappa$-caseins. Biochim. Biophys. Acta, 188 (2), 237-246.

Maubois J.L., Roger L., Brulé G., Piot M., 1979. Hydrolysat enzymatique total des protéines du lactosérum. Obtention et application. Brevet Français $n^{\circ} 7916483$.

Maruyama S., Nakagomi K., Tomizuka N., Suzukı H., 1985. Angiotensin I-converting enzyme inhibitor derived from an enzymatic hydrolyzate of casein. II. Isolation and bradykininpotentiating activity on the uterus and the ileum of rats. Agric. Biol. Chem., 49 (5), 14051409.

Mercier J.C., Maubois J.L., Poznanski S., Ribadeau Dumas B., 1968. Fractionnement préparatif des caséines de vache et de brebis par chromatographie sur D.E.A.E. cellulose en milieu urée et 2-mercaptoethanol. Bull. Soc. Chim. Biol., 50, 521-530.

Mikkanen H.M., Wasserman R., 1980. Enhanced absorption of calcium by casein phosphopeptides in rachitic and normal chicks. J. Nutr., 110, 2141-2148. 
Noelken M., Reibstein M., 1968. Conformation of $\beta$-casein. Arch. Biochem. Biophys., 123 (2), 397-402.

ReImERDES E.H., 1979. Model proteolysis of $\beta$-casein by immobilized trypsin. J. Dairy Res., 46, 223-226.

Ribadeau Dumas B., Grosclaude F., Mercier J.C., 1970. Structure primaire de la caséine $\beta$ bovine. Isolement et composition en amino-acides des peptides trypsiques et des peptides obtenus par action du bromure de cyanogène. Eur. J. Biochem., 14, 451-459.

Ribadeau Dumas B., Brignon G., Grosclaude F., Mercier J.C., 1972. Structure primaire de la caséine $\beta$ bovine. Eur. J. Biochem., 25, 505-514.

ROGER L., 1979. Contributions à la recherche d'une meilleure utilisation en alimentation humaine des composants glucidiques et protéiques du lactosérum grâce à l'emploi des techniques à membrane. Thèse de Docteur-ingénieur en Sciences Agronomiques. ENSA, Rennes.

Schmidt D.G., 1982. Association of caseins and casein micelle structure. In : Developments in Dairy Chemistry. 1. Proteins. Ed. Fox P.F., Applied Science Publishers, London and New York, 61-85.

SwaISGoOd H.E., 1982. Chemistry of milk proteins. In : Developments in Dairy Chemistry. 1. Proteins. Ed. Fox P.F., Applied Science Publishers, London and New York, 1-59.

Terre E., Maubois J.L., Brulé G., Pierre A., 1986. Procédé d'obtention d’une matière enrichie en caséine bêta, appareillage pour la mise en ouvre de ce procédé et application des produits obtenus. Demande brevet français déposée le 10/01/86 ( $\left.\mathrm{N}^{\circ} 8600325\right)$.

Weinstein M.J., Dolittle R.F., 1972. Differential specificities of thrombin, plasmin and trypsin with regard to synthetic and natural substrates and inhibitors. Biochim. Biophys. Acta, 258,
$577-590$. 